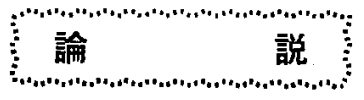

UDC $\quad 621.365 .2: 669.187 .2$

\title{
製鋼用アーク炉大電力操業のための 工学的ならび技術的前提条件
}

\author{
市川 真 人* $^{*}$ \\ What should be done before carrying out High Power Operation \\ of Steelmaking Electric Arc Furnaces
}

Mahito Ichikawa

【概【要】

Schwabe らが製鋼用フーク炉の大電力操業から超大電力操業へと発展をたどる過程で公表 した数値資料にふれ，他方，その努力の歴史的経過をも一般的回想しつつ，いまだ残されて いる問題点があることを指摘し，さらにかが国情下での問題点をも明らかにして，これらを 合わせ列挙，論説し，その解決手段にもられ，特に大電力操業を意図するアーク炉メーカない しニーザが，今後対処すべき電気工学上のポイントを筆者の考劣にしたがって整理し，その努 力を要望喚起したものである。

最後にわが国に乱いて大電力操業を成果あらしめるためには，炉メ一カないしニーザ，周辺 機器材メーカ, 電力会社三者の協力が必須の前提条件であると結んでいる。

\section{1. まえがき}

1965年，W.E. Schwabe らによって提唱された製 鋼用アーク炉の超大電力操業はその後も着実な歩みを 進めていることが，誌上ないし見学者の口を通じて報 ぜられている11〜3)。そしてわが国に扎いても，積極的 にこの大電力操業の方向へ追随する動きが現われてい る。

残念なことであるが後痤を拝する者として，彼らが 事ここにいたつた経過を再度ここに思い浮かへでるる ことは，われわれの今後の心溝えを作る上に执いて参 考に值するだけでなく，そこに，また゚なされなければ ならない問題が线されていることを浮彫りさせてくれ る。また，特にわが国情に照らし解決されねばならな い問題る指摘されねねばなるまい。
大電力操業へ，そして更に超大電力への道をたどる ためには，周倒な計画と準備そこして果效な断行の必 要性が痛感される。

以下, 主として電気工学の立場から，これらの問題 点を整理して読者のご参考供したく思う。

\section{2. 超大電力操業への経過}

よく知られているように， Schwabe らは古くから 各種の実炉ならびにモデル装置について一連の実験 を重ねてきた。特沉1962年代には計算機 I B M 7090を゙ 使って，多くの実炉実験資料に統計処理を施し，アー ク忓の生産性（出鋼 $\mathrm{t} /$ 経過時間）が炬への操業投入 電力(MW)に比例するといら実験式を作りあげ，フー ク炉生産性の飛躍的向上への期待に心をおどらしたか に伺われる。超大電力にいたる予備段階としての大 
電力大電流操業に関する基礎実験のために，共著者， Robinson が勤務している Northwestern Steel \& Wire Co..の150t 炻 2 基が充当されて打り，1基の炉 用変圧器容量を $45 \mathrm{MVAK}$ V格上げ改修している。

他方, 高速度カラーフィルムによるアークの撮影に る成功し，その解析結果から炣内大電力アークの動態 に関する一見識を誘導し，大電流アーク操業の理論上 の卓越性，すなわち，低電気効率をカパーして余りあ る全熱効率の向上，炬壁ライニング・ホットスポット 溶損への楥和奻果などに対する実験的裏つけを与克る ことも試みた。

以上の結果を確信に満ちた口調で述べた大電流操業 に関する論交は，一連のアークカラーフィルムのごく 一部（と彼は称していた）と共に 1963年10月，西独 (Wiesbaden) Kおける第 5 回国際電熱工学会議の席 上で発表された。これら大電力操業に関する基䃈実 験は，事実は1963年当初既佟了して終り，引きつゔ き超大電力への準備期間を経て，同年暮，すなわち， 彼が国際会議の席上発表の直後には, 既に超大電力第 1 号を操業開始している (その際, 前記炉用変王器の 他の一つを $80 \mathrm{MVA}$ に格上げ充当)。

その後の経過については文献1 3゙に述べられている とおりである。その特徵的な点を要約列挙すると，

（1）旧公称 $150 \mathrm{t}$ 炬 1 基で，最高82.5[USt/時]（日 産1980[USt/時]，普通銅) の生産性を記録。

(2) 電力原単位 $=480 \sim 490[\mathrm{kWh} / \mathrm{USt}$ 。

（3）超大電力超大電流アークの形態上の特異性，そ の溶解用熱源としての優秀性（炬壁ライニング寿 命など，ほとんど变化せず)，(4)アーク電流の安 定性 (フリッ力緩和効果)。

（5）新しい24时電極利の開発, 水および水蒸気の炉 内噴射。

（6）実験例に批ける膨大な炉変 1 次回路進相電気設 備容量。

などである。

他方，ヨーロッパでは，オランダのケーブル製造会 社が線材鋼用の $35 \mathrm{t}$ アーク炉 2 基(旧設䚛)に各 $8 \mathrm{MV}$ $\mathrm{A}$ 炉变を採用していたが，同じく $35 \mathrm{t}$ の第 3 号炉では これを15MV A とし, 旧炉 1 基当り年産 4 万 $\mathrm{t}$ から新 炉では 6〜6.5万 t と著しい生産性向上汇成功したこ とを1963年に報じているす。

そして第 4 号炬 $(35 \mathrm{t})$ また $15 \mathrm{MV} \mathrm{A}$ 炉変設固を計 画している。この場合，電力密度增大にともなう激し い煙歴害防止のために，新炉では吸鹿装置を新設して いるが，その他特に本質的な变化などについては何る 述べていない。

Schwabe らの表現”にしたが竞ば，このオランダ の例は通常電力（Regular Power）を越兑沃隹大電力
(High Power)に相当するが，炉容量がそれはど大き くない場合の, 少なくとる超大電力 (Ultra High Power）にはいたらない大電力の籍囲では，大容量炬にお ける唛大電力操業とはかなり本質的に異なるものがあ り，電力采統との相互干啮問題の点でも，また一般的

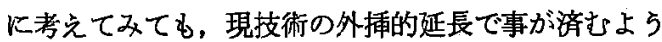
に見受けられる。相対值が大きいとい.うことと，絶対 值が大きいということでは，工学的にも技術的にも， 大きな相異があることを心汇とどめる必要があうう。

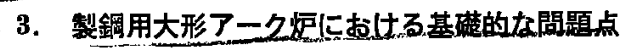

\section{1 怇回路の 3 相䉓気的不平街}

炉容量が小さく $30 \mathrm{t}$ 程度以下の場合には，正弦波な らび 3 相平衡回路を仮定した理論と計算のもとに师電 力などを推定し，炉体㧍よび周辺機器の設計を行い格 別の配虑なく炉操業を行ってもおおむおね支障なく順調 に事が運ばれてきたように見受けられる。炬が70 t 級 になるに怙よんで，ライニングのホットスポットに拉 ける異常局部浴損の問題が発生し，関係者はいゃ応な しに 3 相不平衡の事実を認識させられるにいたったよ 5に見受けられる。

われわれは，いま大容量炉の超大電力・超大電流了 一ク操業といら大目標を前化して当然行われるべき平 衡化対策とは別炏，アーク炬が元来 3 相不平衡装置で あるといら事実を再認識し，その上に立って䇢頭一歩 を進める必要を痛感する。

あらかじ的険討を必要とすることが予想されるポイ ントとして,

（1）各相操業電流と各相アーク電力との関係 $\rightarrow$ 各相 操業適正電流に関する設計上の推定。

（2）電力系におよ洼す電圧および電流不平衡の影響 の程度の予測，中性点電位上昇程度のチェック， 同一母線につながる 3 相大形回転機逆相電力分の チェック。

(3) 電生降下対策。

（4）㥓用変圧器設計に括ける不平衡電流ならび電力 に対する格別の配虑の要否。

などが考えられる。

上記の多くは炬が負荷される釆統ごとに影響の程度 が異り，したがって，一般的な理論解析のほか，わが 国淤ける多くの電力系の場合，ケース・バイ・ケー ス数值的検討を行って予測確認する必要があろう。

具体的に示唆寸れば，理論的検討のためには先人の 羓綘㠶などの活用，その発展的展開と具体的適用化の ための考察；数值的検討のためには， 3 相型交流計算 船などによる数值解析的検討，さらにディジタル計算 
譏により予測数值解を各場合に心して直らに得られる よう,アプリヶーションプログラムの開発とその確立 などが考えられる。上記につき，既に関係者の間で一 部予備的検討が開始されていることは，正䳌を射てい るむのといらべく，力強く思われる。

ここで更に上記(1)に関連し一言触れてみたい。

従来製鋼用アーク炉は目覚ましい大容量化の道をた どってきた。しかるに、「大形师になるにとむなって， 炉が設置され操業が開始されてから，かなり長期間に わたる試行操業期を経たのら，はじめて安定した操業 に入り得ることがある」ということをしばしば聞かさ れた。そして，この時期は現場作業者の長い経過基 づく判断と努力とで，新大型炉の操業指針が確立され るといら調子であったらしいっしかも，各相の適正操業 電流値に対する設計上の見通しないし指針といらよう なるのが設計側から与えられるといらようなことは無 かつたように伺われる。ごれら操業初期に沏ける困難 さは,不平衡回路に基づく不平衡電代降下，その反作用 に基つく電気諸量の不平衡動作に大きな一因が存在す ることが十分予想される。更に並列運転される他の不 平衡アーク炬の影暃もからみ合って、アーク炉の不平 衡動作はいよいよ複雑なるのとなってくることが予見 されるのである。これらは炉の電気容量が大きくなる につれ顕著に現われ，安定した炉操業を会得する事を いよい上困難にするものであるから，十分な検討を設 計の段階に扰いて行い，あらかじめ一つの見通しと見 識とを持つ程度に少なくともなっていなければならな いと思われる。

\section{2 护 2 次回路の電流指示計}

大形纫の 2 次回路には，各相に電流計と切换元式の 線間電圧あるいは対地相電压の指示計が備えられてい るのが一般である。電压計については，対地相電圧と 対溶湯相電圧とは一般的に異なることが考えられ，対 地電圧測定にいか澺味があるか，観測者にはかえ って愦った印象を与えることが恐れられる。この点は 別として，特に溶解末期にいたるまでの激しい電流計 指針のゆれからアーク電流值を知ることは事実上でき ない。炉操業状態に密接に関保する 2 次電気諸量の5 ち, 最も正確な測定を期待できるものは現在の所電流 だけである。作業員が操業状態を知る目安として参考 にすべき電流值の測定が，このような状態に䈯かれた ままでは誠に心細いといわざるを得ないであろら。

幸にして日本電熱工学委員会のホットスボット小委 員会が，ホットスポットによる異常溶損対策の一のと して，電子式の記録式積分電流計を開発し，70 t 炉に
ついて現在データが程まれつつあることは大電力操業 への一のの準備作業としても資する所があるむのと思 5.

今後更に簡便で堅ろうな記録式積分電流計が開発さ れれば，大電力操業の大型炉にはこれらが設置され て，作業者に操業上の目安すを与を得るよらになるで あろら。

\section{3 ア一ク電流波形}

元来非線形であるアークの特性に基づいてアーク電 流波形はひずせ。

モデル炉ならび実炉について，古くから沢山のア一 ク電流ならび近似アーク電王の観测波形オシログラフ が発表されている。このアーク電流波形は炉操業期の 相異, すなから, ボーリング期か, 溶解期か精鍊期か などにとむなって著しく変化すること，更に炉の大き さ，すなわち, 大電流アークか, 比較的小さい電流了 一クかなどによっても波形状態の異なることが知られ ている。

したがって大形师の通常電力から大電力, 更に超大 電力へと進める過程においては，単なる類推で糊塗す ることなくそのつもりになって実测をくり返し，正 確な認識把握に努める必要がある。そこから得られた 师アーク電流に関する一般的データは, 忓用変圧器設 計者に設計基礎資料を提供するにとどまらず，前記積 分電流計の具備すべき周波数特性を決定する見地から る有益な資料となるであるう。

フーク電流波形のオシログラフを見ると，明らかに 顕著な直流分ならび第5調波分を認め得る。直流分なら び第3調波分については，元来零相回路の開放している アーク炉 2 次回路では，各相アークが平衡状態炕ある 限り,これらは存在し得ない忧であるが,各相アーク が常時 3 相平衡状態にあることは当然期待し得ず，し たがって第 3 調波分ならび直流分存在についても詳し く調ベてみる必要があろう。この機会に具体的な操業 状態ご上の代表電流波形について調波分析を行って, 諗識を新たにすることも無䭾なことではあるまい。

また Schwabe は超大電力操業の場合，ボーリング 期㧍よび容解初期に括いて，アーク電圧（電極降下を 含さ近似アーク電圧) 波形はほぼ方形波状をなすと述 ベている゙がこれは小型の 3 相モデル师に括ける詳 細な観測実験波形の報告7)8) と奇しくも一致している。 他方，Schwabe はまた，その他の操業期間に拈いて は新開発電極材の珄賀之の関連に拈いて，アーク電圧 波形が通常電力操業の場合に比し，正弦波形に近いも のになっている, とす述べている。 


\section{4 ライニングホットスポット対策}

Schwabe は大電流操業の段階でもまた暜大䉓流探 業でも，いわゆる激動相(wild phase)に起因なるライ ニングの異常溶損をほとんど問題にしていない。事夷 彼が挙げているライニング寿命は常に 150 上ート程度 以上に達しておうり，その理由づけとして低電压大電流 アークの短小性（超大電力の場合には，合わせて蒸気 噴射の効果をも）を高らかに歌っている。

しかし，わが国における大形炉通常電力操業の実例 では、本問題に関する深刻な経過もあり，いたずらに楽 観することは許されないよらに思われる。本問題解決 のため, 前記ホットスポット小委会が忓壁ラィニング の溶損状態の実例を行5べく，新しい計測法にとり組 み地道な基碟研究に従事しているが，いまだ見通しを 得るにいたっていない事は残念なことである。本問題 に関連し溶損しつつある炉壁表面温度の連綕測定のた め, Schwabe は黑鉛棒に上る新しい測温法を開発実 用化して叔り"，その意照的な研究態度には学ぶべき わのがあることを身にしみて感じさせられる。

\section{4 フリッカ}

Schwabe は超大電力操業(80MVA灯変) の揚合, これを大電力操業 ( $45 \mathrm{MV}$ A炬変) の場合に比べて電 流動摇記録回数（それぞれ基準電流值を超過した電流 状態の発生回数）を実測している(1,2)。その結果に上 れば，予想に反し，前者は後者の0.6 0.2倍程度に护 さまっていることが示されている。

上記測定実験は，特に高速リスポンスでもないでく ありふれた測定器によったものではあるけれどもよ り大きな電カアーク操業である任ど, 動摇頻度が少な いことを示するのとして，フリッカの見地からも，特 筆に值する記録資料である。しかも，この記録値がそ れぞれの場合，1ヒートごとの此校測定俌でなく(むし そらであるとすれば，超大電力の場合はより短い時間 期間の発生回数を数えていることになる）操業 1 時間 当りの比較測定である事が注目に值する。すなわち， ある意味では，この值をそのままフリッカ対応量とし て上さをらに受けとれる。

しかしここで注意を要することは，通常電力，大電 力,超大電力，いずれの場合も電力系統の方が同一であ るならば，超大電力の場合，動摇頻度は低下しても各動 摇ごとの节烈度絶対值は当然大きくなる。したがって 一概にフリッカが減少すると思い込七事はきわめて伦 険であり,系統容量,ないしその噌大变更計画に応じて
ケース・ハイ・ケースに事前の検討を必要とするであ ろら。

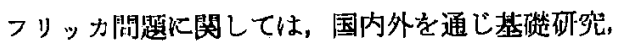
測定法ならび対策実施例にわたる溦大な量の報告が積 まれつつある。そのなかでり，日本電熱工委フリッッ カ小委主查神宮司武雄氏 (電力中研) を中心とする活 躍の成果は世界的譛碚にたと兄得るむのであり, 近く 報告書の形でとりまとめられ公表公刊が予定されてい る。これの有力な参考資料を関係者は活用すべきであ ろら。

フリッカは産業の発展ならびこれに見合らべき電力 需要の增大にともなら一つの必要と見なされる。今後 も新しい巧妙な防止対策法が工夫発裴されるかる知れ ないが，本問題が公害問題として大きく表面化するに さきだって，フーク师ューザも同メーカも，また電力 会社も，この対策手段必須の附随投資上して積極的に Łりあげるべき段階に達しているのではなかろらか？

\section{5 電圧降下対策}

超大電力操業が予期した大きな生産性を確保するた めには，予期の超大電力が炬に投入され得る上5,炉変 1 次側電圧が強固に維持され得ることを前提とする。 事実，文献”は 3 号炉が並列大電力操業を行うこと によって，超大電力操業4号炉の生産性がその単独操業 時に比し著しく低下することにふれている。そのため 上記設備(上記 2 湴の他ミルが並列目荷されている) は，第 2 章中，(6)項で既に指摘したよ5K，計 $150 \mathrm{MV}$ A 飞垟する進相容量を师変 1 次側に設備している。明 らかにこれは力㴋改善設備ではなく電圧維持設備であ る。実験設備としてならば話は别であるが，この様に 膨大な進相設确を必要とする系統ないし，主変圧器模 成の場合には，迢大電力慢業も初期投資上の経济的見 地から画凔に陏寸可能性があるといわざるを得まい。 この点ならび 2 次最高タップ電圧の設計上の選択にお いても，予備的数值検尉を行らために，既に3・1節で示 唆した計買手法が有效にいかされる得るはずである。

\section{4. アーク炣熱系の解析}

3 相不平衡回路であるアーク师 2 次系について,各相 等電流操業を仮定した計算のもとでは，よく知られて いる上らに第3相が激動相之なり，第2相炕る中央相の アーク電力は中間の大きさとなる事が示される。しか るに公表されているほとんどすべての実例が，中央相 対向炉壁面に最も激しいホットスボットの生じること を報じている。実際の操業では必ずしも等電流操業と なっているわけではないから，計算の前提は既に筋れ 
去っているわけであるが，少なくとも電気工学の立場 から各相アーク電力が各相操業電流状態に応じてどの よ5になり得るか、3.1 節に还べた計算手法によって 明らかになし得るはずであり，ホットスポット対策の 見地からも重要な研究課題としてとりあげられねね゙゙な らない(本問題を系統的により报った文献を偭聞にし て知らない)。

炬壁などホットスポットの閣題を論ずるためには， 上記電気工学上の解析之並行して, 元来中心刘称構造 となっていないアーク炉熱系の熱的解析を行う必要が ある。しかるに, アーク炉の様に複雑な境界条件を持 つ3次元構造の熱系解析を行らことは, 現在知られて いるジィシタルル計算機あるいはフナログ計算機化訴 えても事実上不可能である。そのためには一般熱系解 析専用の一㣫のハイブリッド計算機に訴えざるを得な い事が予想され，その開発研究に各方面の理解が期待 される次第である。この方面の計算があるる程度でも 可能となれば，大電力ないし超大電力操業時の炻壁木 ットスポット対策に有力な資料を提供する事が可能に なるものと期待される。

\section{5.むすび}

大電力大容量のアーク炉群がスクラップ処理扎よび同 装入設備から出鋼設備にいたるまで一つの大きなシス テムを構成しよらとしている今日，自動制御化の問題 も当然ここにとりあげられてしかるべきであろら。わ が国に拉いてむ既に一部でその緹につき始めているこ とは喜ばしいことであるが，紙面も既に尽き叙述を剕 愛することをご寛容いただきたい。

最後に一言して結びの言葉とする。

大電力ないし超大電力操業フーク怇の開発を強力に 押し進めその成果を期するためには，筆者が超大電力 操業を初めて紹介した当時2) 既に指摘したように, 炉
メーカないしニーザ，周辺機器材メーカならび電力会 社三者間の相互信頼と協力とが前提必要条件として確 立されなければならない。そしてこれは㓑して各三 者の利益にそれでれ合致するものであるから，当然， 成立可能であると信ぜられる。なお本文は筆者のかな り独断的な思考をあからさま述べたものであり，将 来あやまる所あることを拈それているが，浅学非才の 業としてご寛容を得る事ができれば幸である。

\section{〔文献〕}

1) C.G. Robinson \& W.E. Schwabe : J. Metals, $17(1965) 1,75$

2) 市川：電気炉，2 (1965) 6，2 [1)の和交紹介]

3) W.E. Schwabe \& W.E. Robinson: J. Metals, 19 (1967) 4, 67

4) W.E. Schwabe : Principles of high-production electric steel furnace operation, 5th UIE Congress Paper No. 123 ; [曾々木訳, 電気炉, 1 (1964) 3) ; 市川：ライニンク摩損問題（電気 炉, 2(1965) 3 参照]

5) B. Ulrich : Wirtschaftlichkeit mittelgrosser Lichtbogenöfen in der Stahlindustrie mit hoher Transformatorleistung in nichtinte grierten Stahlwerken, 5th UIE Congress Paper No.111 (Oct. 1963)

6) 本田：電学誌, 86 (1966) 929, 227

7) J. Schiffarth : Ein Beitrag zur Bekämpfung der scharfen Phase bei Lichtbogenöfen unter Berücksichtigung der nicht sinusförmigen Lichtbogenspannung, 5 th UIE Congress Paper No. 136 (Oct. 1963)

8）市川：電気炉，2（1965） 9 